methods: We examined 107 children with a histologically verified diagnosis of chronic gastritis (CG) in combination with CD. The first group consisted of 58 children with CG and newly diagnosed CD. The second group included of 49 children with CG, CD who adhering a gluten-free diet for at least 1 year. $\mathrm{IgG}$ antibodies to $\mathrm{H}+/ \mathrm{K}+$ ATPase of parietal cells of gastric mucosa -APCA $(\mathrm{U} / \mathrm{ml})$ and $\operatorname{IgG}$ antibodies to Castle's intrinsic factor $(\mathrm{U} / \mathrm{ml})$ were determined by the enzyme-linked immunosorbent assay. We performed multivariate correlation and regression analysis, using IBM SPSS Statistics 3 software package.

Results AG was diagnosed in children only in group 1 $12,1 \%$, in group 2nd AG wasn't detected - 0,0\% ( $\mathrm{p}<0,01)$. Multivariate correlation and regression analysis made it possible to identify a number of significant factors and criteria for $A G$ in children with $\mathrm{CD}$ : the presence of symptoms of $\mathrm{CD}$ for 3 or more years before the diagnosis $(r=0,262 ; \mathrm{p}<0,05)$; concomitant autoimmune thyroiditis $(\mathrm{r}=0,390 ; \mathrm{p}<0,001)$; concomitant type 1 diabetes mellitus $(\mathrm{r}=0,390 ; \mathrm{p}<0,001)$; family autoimmune pathology history $(\mathrm{r}=0,298 ; \mathrm{p}<0,05)$; epigastric pain on palpation $(\mathrm{r}=0,364 ; \mathrm{p}<0,001)$; the presence of dyspeptic complaints $(\mathrm{r}=0,417 ; \mathrm{p}<0,001)$ and fasting abdominal pain ( $\mathrm{r} 0,336 ; \mathrm{p}<0,01)$; white coating of the tongue $(\mathrm{r}=0,349 ; \mathrm{p}<0,01)$; goitre $(\mathrm{r}=0,422 \mathrm{p}<0,001)$; severe lymphocytic infiltration of gastric mucosa $(\mathrm{r}=0,289 ; \mathrm{p}<0,05)$, focal destruction of the gastric glands $(r=0,698 ; \mathrm{p}<0,001)$; atrophy of the gastric glands $(r=0,573 ; p<0,001)$, neutrophilic infiltration in the fundus of the stomach $(\mathrm{r}=0,44 ; 1 \mathrm{p}<0,001)$; the presence of atrophy of the glands $(r=0,441 ; p<0,001)$ and fibrosis of the stroma $(=0,296 ; \mathrm{p}<0,05)$ of the antrum; the small intestine atrophy according to Marsh $\geq 2$ grade $(r=0,291 ; p<0,05)$ and the presence of the HLA-DQ8 haplotype $(r=0,588 ; p<0,01)$. Simple logistic regression equation revealed a high likelihood of $A G$ in patients with $C D$, who has 9 and more described factors. Visual assessment by the ROC-curve of the obtained mathematical model presented significant predictive ability (area under the curve $=0,987$ ).

Conclusion detection of the revealed risk factors promotes early diagnosis of $A G$ in children with $C D$.

\section{INTEGRATION OF A CHILD WITH CELIAC DISEASE INTO A PRESCHOOL INSTITUTION}

Jelena Andesilić, Željko Jovanović, Karmen Beljan, Nives Radošević Quadranti. Faculty of Health Studies University of Rijeka

10.1136/archdischild-2021-europaediatrics.272

Introduction Celiac disease is a small intestine disease of chronic etiology that arises as inflammatory response of intestinal mucosa to gliadin, gluten protein component contained in wheat, rye, barley and oats. Celiac disease is necessary lifetime implementation of a gluten-free diet. Preschool institution provides conditions for each child to achieve individual needs, opportunities and interest. The aim of the research was to determine the attitudes of educators, examine their knowledge of celiac disease and gluten-free diet and evaluate competences to work with children suffering from celiac disease.

Subjects, methods and results The survey was conducted with a survey of 20 questions in nine preschool institutions in Primorsko-Goranska County. A total of 260 educators were surveyed, of which 167 valid questionnaires on which survey was based. $97.6 \%$ of educators surveyed know what celiac disease is. Most have answered that celiac disease cannot get over (66.47\%). $73.65 \%$ had no experience of working with children with celiac disease, while $56.29 \%$ of educators rated themselves competent to work. That they are not sufficiently informed about celiac disease answered $77.25 \%$ of educators. $39.52 \%$ of educators have encountered literature related to celiac disease, while only $10.18 \%$ participated in education. Caring for a child who suffers from celiac disease $53.89 \%$ do not experience demanding, while $55.69 \%$ respond that the inclusion of a child suffering from celiac disease in the regular group does not requires changes in educational work. The attitude of educators to kindergarten there are good conditions for the care of a child suffering from celiac disease $61,68 \%$. Out of a total of 93 educators who were rated competent to work with children suffering from celiac disease, $66.67 \%$ completed some form of professional training that provides them with safety in their work.

Conclusion Research shows that there is awareness among educators about celiac disease, anyone with experience in working with children with celiac disease evaluates it positive, and educators who are considered competent to work with children's patients with celiac disease have completed some form of education. Integration a child suffering from celiac disease requires cooperation between educators, parents, kitchen workers and the health manager. Adapting educational groups and kindergarten kitchens are key in integration planning. It's important ensure support for educators and carry out continuous training on the topic of celiac disease with the aim of strengthening the competences of educators to work with children with celiac disease, adapt the space of the educational group for the stay child, carry out professional development of kitchen workers for the preparation of gluten-free meals, adjust the kitchen area and draw up instructions for preparation of gluten-free meals with the aim of preventing contamination of meals, and encourage continuous cooperation with the Association of Celiac Patients.

\section{PREVALENCE OF UPPER GASTROINTESTINAL TRACT ENDOSCOPIES AT THE PEDIATRIC CLINIC OF THE CLINICAL HOSPITAL CENTER RIJEKA FROM 2007 TO 2017}

Iva Dumančić ${ }^{*}$ Kristina Baraba Dekanić, Ivona Butorac Ahel, Goran Palčevski. Pediatric Clinic of the Clinical Hospital Rijeka, Rijeka

\subsection{6/archdischild-2021-europaediatrics.273}

Aim The aim of the study was to determine the frequency of individual indications, total number of esophagogastroduodenoscopies (EGDS) and pathohistological (PH) findings at the Pediatric Clinic, Clinical Hospital Center ( CHC ) Rijeka. The frequency of therapeutic interventions for foreign body extraction, the most common types of ingested objects, the frequency of ingestion of acid and alkalis, and the placement of PEG were also considered.

Materials and Methods The medical records of all patients undergoing EGDS from January 2007 to December 2017 were reviewed retrospectively. In the analysis of the obtained data, the reasons for performing EGDS in each patient were recorded. The sample for $\mathrm{PH}$ analysis was taken based on the assesment of the physician who performed the examination (pediatric gastroenterologist). 